\title{
Genetic damage in mobile phone users: some preliminary findings
}

\author{
Gursatej Gandhi, Anita \\ Department of Human Genetics, Guru Nanak Dev University, Amritsar 143005.
}

BACKGROUND : The impact of microwave (MW)/radio frequency radiation (RFR) on important biological parameters is probably more than a simply thermal one. Exposure to radio frequency (RF) signals generated by the use of cellular telephones have increased dramatically and reported to affect physiological, neurological, cognitive and behavioural changes and to induce, initiate and promote carcinogenesis. Genotoxicity of RFR has also been reported in various test systems after in vitro and/or in vivo exposure but none in mobile phone users.

AIMS : In the present study, DNA and chromosomal damage investigations were carried out on the peripheral blood lymphocytes of individuals using mobile phones, being exposed to MW frequency ranging from 800 to $2000 \mathrm{MHz}$.

METHODS : DNA damage was assessed using the single cell gel electrophoresis assay and aneugenic and clastogenic damage by the in vivo capillary blood micronucleus test (MNT) in a total of 24 mobile phone users. RESULTS : Mean comet tail length $(26.76 \pm 0.054 \mu \mathrm{m}$; $39.75 \%$ of cells damaged) in mobile phone users was highly significant from that in the control group. The in vivo capillary blood MNT also revealed highly significant $(0.25)$ frequency of micronucleated (MNd) cells.

CONCLUSIONS : These results highlight a correlation between mobile phone use (exposure to RFR) and genetic damage and require interim public health actions in the wake of widespread use of mobile telephony.

Key words: DNA damage; micronuclei; microwaves;

The continued spread of mobile telephony is of serious concerns since a relationship between electromagnetic fields radio frequency (RF) and microwave (MW) radiation and adverse health effects at low intensity exposures exists. The cell (mobile) phone is an appliance that requires that it be held close to or touching the head, which is the most sensitive organ of the body. This has initiated a spate of studies to enquire for effects on user health and explore mechanisms of interaction responsible for reported biological sequel on humans, animals and organic cells from acute and chronic exposures from mobile phone frequencies. Generally, the higher the frequency the less able electromagnetic radiation is to penetrate materials. However, even millimetre waves penetrate irradiated skin to a depth of $1 \mathrm{~mm}$, while the microcirculatory system of the skin functions at $150 \mu \mathrm{m}$ and so is fully accessible to EHF exposure. Lower frequencies can however penetrate further. The mode of interaction between nonionising electromagnetic radiation and tissue is also highly dependent on the dielectric behaviour of water and dissolved ions at RF and MW frequencies.

Wireless communication systems operate in the 400$2000 \mathrm{MHz}$ range, differing in respect to frequency usage in different countries and on different continents. In fact, the use of the digital communication system that transmits radio frequency radiations (RFR) at higher frequencies in this range has increased dramatically. The Indian mobile phone market has also shown dramatic ascent and has 40.6 million users with the global system of mobile communication (GSM) service having 32.02 million registered users and the code division multiple access (CDMA) subscribers with 8.6 million (www.Indianews.com, October 2004). The potential for health effects from low intensity RF/MW 
radiation from the 'weight of the scientific evidence' points to a relationship between RF/MW and illness.

Some of the biological effects associated with RF radiation include $\mathrm{RF}$ sickness, electroencephalographic changes, cell proliferation ${ }^{[1]}$ and blood pressure changes, blood-brain barrier leakage, ${ }^{[2]}$ altered EEG patterns ${ }^{[3]}$ and decreased fertility in mice. ${ }^{[4]}$ Cancer risks and genotoxicity from exposure to RF fields in vivo and in vitro have rather been points of cynosure since equivocal evidences exist. ${ }^{[5-8]}$ Apparently no studies have documented genotoxicity in mobile phone users. The present investigation reports DNA and chromosomal damage in peripheral blood lymphocytes of mobile phone users by the single cell gel electrophoresis (SCGE/Comet) assay and the capillary blood in vivo micronucleus test (MNT). The study was cleared by the institutional ethical committee.

\section{Methods}

The subjects were selected on the basis of period of mobile phone use. Voluntary written informed consent was obtained and details on their diet, life style and health status were recorded. Age- and sex-matched healthy individuals who had never used the mobile phone formed the control group. Finger-prick blood samples were collected in heparinised eppendorf tubes, transported in an ice-box to the laboratory and processed for the comet assay ${ }^{[9],[10]}$ and the MNT ${ }^{[11]}$ within 3-4 h of collection. Peripheral blood cells were embedded in agarose on agar-coated slides, lysed under alkaline conditions to partially unwind DNA, electrophorosed followed by silver staining. Both the normal cells and comets (100/sample) were scored and DNA migration lengths were measured less than under 40x using an ocular micrometer calibrated with the help of a stage micrometer.

The MNT is based on the observation that when cells with chromatid breaks or exchanges undergo mitosis, a sizeable portion of chromatin that is not included in the daughter nuclei, forms a single micronucleus or multiple micronuclei. The in vivo MNT in lymphocytes of human capillary blood is a simpler, convenient, informative in vivo cytogenetic technique and its precision makes it more suitable to large-scale investigations and human biomonitoring studies. To $0.06-1.00 \mathrm{ml}$ blood obtained through finger puncture, $0.3 \%$ methyl cellulose was added to blood in a $\mathrm{v} / \mathrm{v}$ ratio of $1: 3$ and kept in a water bath $\left(37^{\circ} \mathrm{C}\right.$ for $40-60 \mathrm{~min}$ ). The lymphocyte suspension was then centrifuged at $1000 \mathrm{rpm}$ for $6 \mathrm{~min}$ and the pellet, suspended in $43 \mu \mathrm{l}$ of remaining supernatant, was used to make smears on glass slides. Air-dried smears were fixed in $100 \%$ methanol for $1 \mathrm{~min}$ and stained in buffered Giemsa (pH 6.4, 1:10, 20 min). Coded preparations were scored (2000 cells/sample at $40 x$ ) for MN [small, spherical and separated chromatin masses in small ( $\mathrm{T}$ ) lymphocytes]. The presence of micronuclei (as per the given criteria) ${ }^{[12]}$ in the cells was confirmed at $100 \times$ under oil immersion and randomly by another observer. The main nucleus and MN show dark blue against the light blue cytoplasm.

\section{Results}

Peripheral blood lymphocytes of individuals $(n=24)$ using mobile phones were processed in order to assess whether mobile phone usage induces chromosomal and DNA damage. All those evaluated for the MN test $(n=20)$ were also investigated for DNA damage and so are included among those $(n=24)$ for which the SCGE assay was performed [Table 1]. Samples from age-, sex- and socioeconomic status-matched controls $(n=11)$ were also processed for DNA damage $(n=10)$ and the MN test $(n=8)$. There were only three females among mobile phone users; very few smokers $(n=2)$ and those taking alcohol $(n=2)$. None of the subjects had any family history of any genetic anomaly or major illness nor had they undergone irradiation examination or been exposed to organic solvents and for the last 6 months none have been on medication or on drugs and no one did any regular exercise. The reproductive performance of married individuals $(n=7)$ was known to be normal. However, some of the selected individuals ( $n=4)$ complained about sleeplessness, memory loss, less attentivity and heart pain, which they felt was associated with mobile phone vibrations. The usage of phone varied from one to 5 years with most persons ( $n=20)$ using it from 2 to 3 years. The specific absorption rate (SAR) gives estimates of the radiated energy given out by the cell phone and being absorbed 


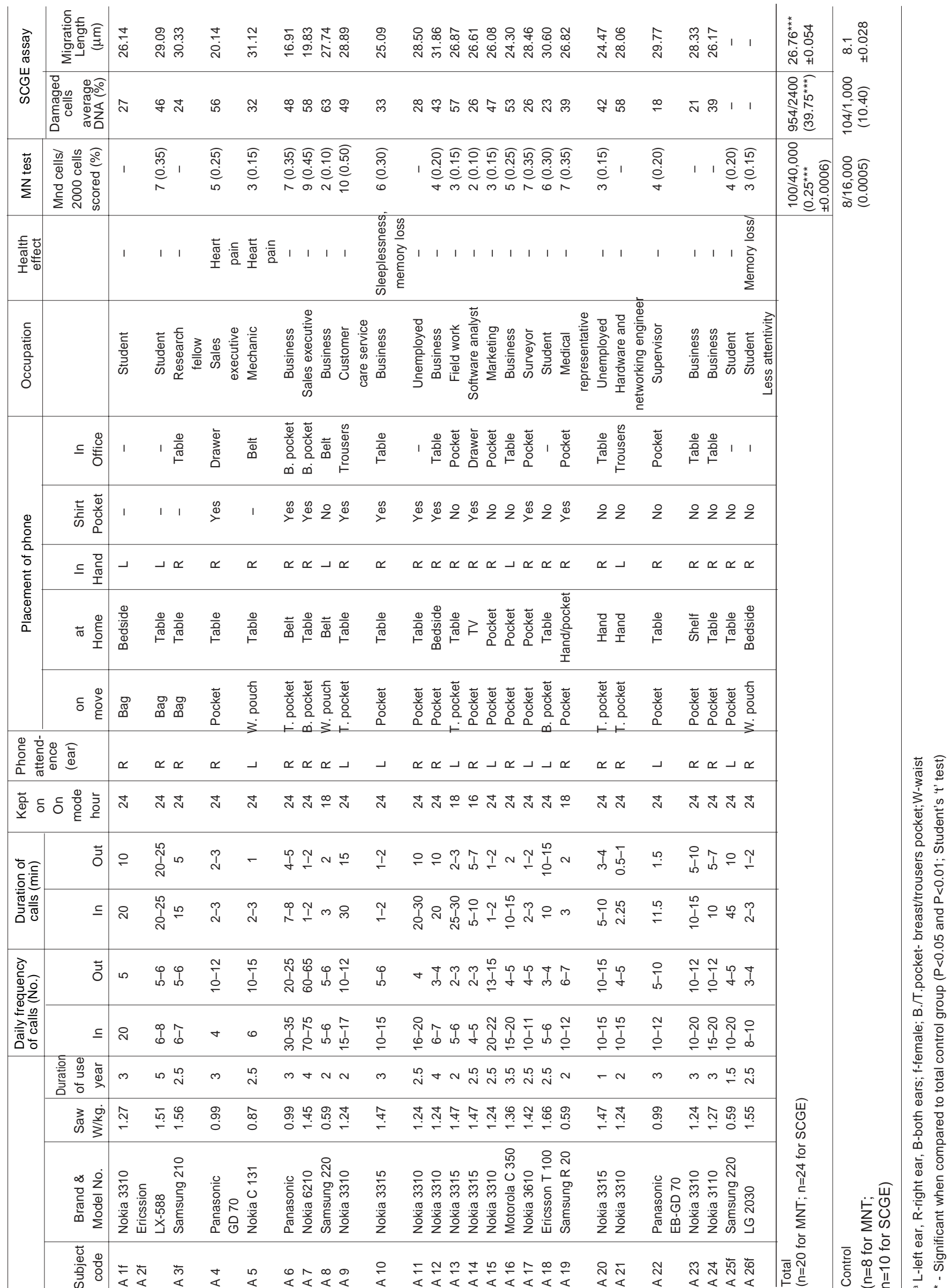


into the body tissues in terms of Watts per kilogram (W/ $\mathrm{kg})$ or milliWatts per gram $(\mu \mathrm{W} / \mathrm{g})$ of body weight. The popular phone brands were Nokia (SAR $=0.87-1.47 \mathrm{~W}$ / $\mathrm{kg}$ ) with 15 users, Samsung (SAR $=0.59$ and $1.56 \mathrm{~W} /$ $\mathrm{kg}$ ) with four, and Panasonic (SAR $=0.99 \mathrm{~W} / \mathrm{kg}$ ) with three users. The daily use of phone ranged from 1 to $15 \mathrm{~h}$, which actually contributes to the daily direct exposure in the real sense though the mobile was kept on 'On' mode for $24 \mathrm{~h}$ by 22 subjects. There were 17 individuals attending phones from the right ears whereas nine attended from left ears. None subjects used any protective cases for mobile phones and no one among them availed of any special offer (s).

The SCGE assay results demonstrated DNA migration in $\sim 40 \%$ (39.75) of mobile phone users with a mean tail length of $26.76 \pm 0.054 \mu \mathrm{m}$ (range $16.91 \pm 0.192$ to $31.86 \pm 0.252 \mu \mathrm{m}$ ) which was significantly increased from the control value (8.11 $\pm 0.028 \mu \mathrm{m}$ with $10.40 \%$ of cell damage). The maximum tail length was observed in the blood sample (with $43 \%$ cell damage) of a 28 -year-old male who was dealing in automobile spare parts and was using Nokia $3310(\mathrm{SAR}=1.27 \mathrm{~W} / \mathrm{kg})$ for the past 4 years. At the time of sample collection his daily communication on mobile phone was from 1.5 to $2.0 \mathrm{~h}$. The higher value of comet tail length may be due to longer duration of mobile phone use as he is a nonsmoker, nonalcoholic, and nonvegetarian. Similarly in peripheral blood lymphocytes of another male aged 21 years (a two-wheeler mechanic), a long-tail length (31.12 $\mu \mathrm{m}$, with $32 \%$ damaged cells) was observed. He had been using Nokia $\mathrm{C} 131$ (SAR $=0.87 \mathrm{~W} / \mathrm{kg}$ ) for 2.5 years with daily use of 1.5-2 $\mathrm{h}$ and probably with some exposure at his work place also contributing towards the genetic damage observed in his PBLs. The maximum number of damaged cells (63\%) was observed in a male (24 years) using Samsung 220 (SAR $=0.59 \mathrm{~W} / \mathrm{kg})$ for 2 years with $1-1.5 \mathrm{~h}$ daily mobile phone usage. Among the control individuals, comet tail lengths ranged from $6.03 \pm 0.130$ to $10.3 \pm 0.090 \mu \mathrm{m}$.

Chromosomal damage (aneugenic/clastogenic) was also scored for in 20 individuals and in eight controls. There was a marked difference in the frequencies of micronucleated ( $\mathrm{MNd}$ ) cells among subjects (av. 0.25 MNd cells) and the control group (av. 0.05 MNd cells; only $3.8 \%$ had $\mathrm{MN}$ ). The maximum $\mathrm{MNd}$ cell frequency of 0.50 was observed in a male (24 years) who had been using Nokia 3310 (SAR $=1.24 \mathrm{~W} / \mathrm{kg})$ for 2 years with a daily use of 8-9 h and working in the customer-care department of a mobile phone company. The minimum frequency of MNd cells ( 0.10 each) was observed in two males aged 24 and 28 years, a businessman and software analyst, respectively. Both were using mobile phones for 2 years with SAR of 0.59 and $1.47 \mathrm{~W} / \mathrm{kg}$ and with a daily use of $1-1.5$ and $3-4 \mathrm{~h}$, respectively.

\section{Discussion}

Both the MNT and SCGE assay were employed for assessing any genetic damage in mobile phone users being exposed to mobile phone MW frequency ranging from 800 to $2000 \mathrm{MHz}$. Significant increases in DNA tail lengths, of cells with DNA damage and in MNd cells of mobile phone users were observed. Data for DNA and chromosomal damage of female subjects were clubbed with that of male subjects, as there were no differences in the values. No significant influence of sex on $\mathrm{MN}$ frequency has been also reported in the in vivo capillary blood MN test. ${ }^{[11]}$ More DNA damage than micronuclei induction in the same PBL samples was noted. This is because the MN test detects injuries that survive at least one mitotic cycle, while the comet assay identifies repairable injuries or alkali-labile sites, which cause an increased intensity of comet tail length but do not cause $\mathrm{MN}$ induction. It has been reported that when the exposure to genotoxic agents is small, even though there may be positive results in the comet assay, correspondingly positive results in the $\mathrm{MN}$ test may not occur. $^{[13]}$

The presence of $\mathrm{MNd}$ cells was observed in only $~ 4 \%$ of control individuals. This low frequency may be due to good dietary patterns in the absence of smoking and drinking habits. Punjabi people have a fairly good intake of fruits and vegetables, which are associated with reduced risks for cancers. The carotenoids and carotenoid-rich foods can influence DNA damage and repair by modulating discrete stages in the DNA repair mechanisms. ${ }^{[14]}$ The effects of mobile use can be curbed depending upon the availability of dietary antioxidants, ${ }^{[15]}$ consumption of ethanol, ${ }^{[16]}$ conditions like psychological stress $^{[17]}$ and strenuous physical exercise. ${ }^{[18]}$ This emphasizes the speculation that some individuals may 
be more susceptible to the effects of RFR exposure. ${ }^{[19]}$

The results of the present study are in tune with some reports in the literature. Chromosome aberrations and micronuclei were significantly higher than the controls, in a group of workers exposed to 10 to $50 \mu \mathrm{W} / \mathrm{cm}^{2}$ of radar producing $\mathrm{MWs}$ and/or also exposed to about 5 ppm of vinyl chloride monomer, a known carcinogen. ${ }^{20]}$ Human lymphocytes exposed to MW radiation produced a dose response increase in chromosome aberrations. ${ }^{[1]}$

Occupational exposure to MWs in 12 workers had significantly increased chromosome damage as well as disturbances in the distribution of cells over the first-, second- and third-mitotic divisions. ${ }^{[22]}$ In rat brain cells exposure of both continuous wave (CW) and pulsed microwaves (PW) caused significant increase in singleand double-strand DNA breakage with $\mathrm{PW}$ causing more damage than $\mathrm{CW} .{ }^{[6]}$ Neither direct chromosomal damage (chromosome aberrations and SCEs) nor tail moment and tail lengths increased in comet assay when human whole blood cells were exposed to continuous 935.2 MHz (SAR 0.3-0.4 W/kg) but a synergistic effect after RFR exposure followed by mitomycin- $C$ was reported in the form of an increase in SCEs. ${ }^{[23]}$ In vitro exposure of human peripheral blood lymphocytes to continuous $830 \mathrm{MHz}$ EMF (SAR 1.65-8.8 W/kg) for $72 \mathrm{~h}$ caused losses and gains of chromosomes. A linear increase in Chr \# 17 aneuploidy was observed as a function of SAR value at $34.5-37.5^{\circ} \mathrm{C}$ indicating that the genotoxic effect of the EMF is elicited via a nonthermal pathway. ${ }^{[24]}$

Some contrary reports include: absence of primary DNA damage in human glioblastoma and mouse fibroblast cells exposed to $835.62 \mathrm{MHz}$ (FDMA) and 847.74 MHz (CDMA) RFR, respectively, at SAR 0.6 W/ $\mathrm{kg} .{ }^{[8]}$ Equal number of DNA breaks in rat lymphocytes were reported in both controls and animals exposed to $945 \mathrm{MHz}$ RFR for 1-5 weeks. ${ }^{[25] H u m a n}$ blood lymphocytes exposed to $837 \mathrm{MHz}$ (TDMA), $837 \mathrm{MHz}$ (CDMA) and $1900 \mathrm{MHz}$ (PCS) showed no increase in primary DNA damage or of MNd binucleated human blood lymphocytes. ${ }^{[26]} \mathrm{PBL}$ cultures of 20 healthy donors exposed to CW intermittent exposure and GSM signals did not increase MN frequency in the cytokinesis - block MN assay. ${ }^{[27]} \mathrm{PBL}$ cultures exposed to both $\mathrm{CW}$ and $\mathrm{PW}$ $1.9 \mathrm{GHz}$ RFR at SAR 0-10 W/kg for $24 \mathrm{~h}$ revealed no significant increase in DNA damage or MN frequency. ${ }^{[28]}$ No statistically significant differences in the level of DNA damage or apoptosis by SCGE assay and annexin V affinity assay, respectively were observed between sham-treated and RF- exposed Molt-4T lymphoblastoid cells. ${ }^{[29]}$

In the light of this literature it can be observed that the studies documenting positive genotoxicity are those where there is mostly in vivo occupational exposure to RFR of mobile phone range. The present study clearly demonstrates the same, albeit the exposure is directly through mobile phone use. There is a potential for a very large worldwide public health impact in the wake of the results of this study and calls for interim public health protective measures.

\section{References}

1. Kwee S, Resmark P. Changes in cell proliferation due to environmental non-ionizing radiation 2. Microwave radiation. Bioelectrochem Bioenerg 1998;44:251-5.

2. Salford LG, Brun AE, Ederhardt JL, Malmgren L, Perssson BR. Nerve cell damage in mammalian brain after exposure to microwaves from GSM mobile phones. Environ Health Prespect 2003;111:881-3.

3. Kramarenko AV, Tan U. Effects of high frequency electromagnetic fields on human EEG: a brain mapping study. Int J Neurosci 2003;113:1007-19.

4. Magras IN, Xenos TD. RF radiation-induced changes in the prenatal development of mice. Bioelectromag 1997;18:455-61.

5. Anane R, Dulou PE, Taxile M, Geffard M, Crespeau FL, Veyret B. Effects of GSM-900 microwaves on DMBAinduced mammary gland tumors in female SpragueDawley rats. Radiat Res 2003;160:492-7.

6. Lai $H$, Singh NP. Single and double strand DNA breaks in rat brain cells after acute exposure to radiofrequency electromagnetic radiation. Int J Radiat Biol 1996;69:513-21.

7. Moulder JE, Erdriech LS, Malyapa RS, Merritt J, Pickard WF, Vijayalaxmi. Cell phones and cancer: what is the evidence for a connection: Radiat Res 1999;151:513-31.

8. Malyapa RS, Ahern EW, Straube WL, Moros EG, Pickard WF, Roti Roti JL. Measurement of DNA damage after exposure to electromagnetic radiation in the cellular phone communication frequency band (835.63 and 847.74 MHz). Radiat Res 1997;148:618-27.

9. Singh NP, McCoy MT, Tice RR, Schneider EL. A simple technique for quantitation of low levels of DNA damage in individual cells. Exp Cell Res 1988;175:184-91.

10. Ahuja YR, Saran R. Alkaline single cell gel electrophoresis Assay I. Protocol. Cytol Genet 1999;34:57-62.

11. Xue KX, Ma GJ, Wang $S$, Zhou $P$. The in vivo micronucleus test in human capillary blood lymphocytes: Methodological studies and effect of ageing. Mutat Res 1992;278:259-64. 
12. Tolbert PE, Shy CM, Allen JW. Micronuclei and other nuclear anomalies in buccal smears; methods development. Mutat Res 1992;271:69-77.

13. Van Goethem F, Lison D, Kirsch-Volders M. Comparative evaluation of the in vitro micronucleus test and the alkaline single cell gel electrophoresis assay for the detection of DNA damaging agents: genotoxic effects of cobalt powder, tungsten carbide and cobalt-tungsten carbide. Mutat Res 1997;392:31-43.

14. Astley SB, Elliott RM, Archer DB, Southon S). Evidence that dietary supplementation with carotenoids and carotenoid-rich food modulates the DNA damage: repair balance in human lymphocytes. Br J Nutr 2004;91:63-72.

15. Arcioma OI. Nutrition and health aspects of free radicals and antioxidants. Food Chem. Toxicol 1994;32:671-83.

16. Kursoe I, Higuchi H, Kato S, Miura S, Ishii H. Ethanol induced oxidative stress in the liver. Alcohol Clin Exp Res 1996;20:77A-85A.

17. Haque MF, Aghabeighi B, Wasil M, Hodges S, Harris M. Oxygen free radicals in idiopathic facial pain. Bangaladesh Med Res Coun Bull 1994;20:104-16.

18. Clarkson PM. Antioxidants and physical performance. Crit Rev Food Sci Nutri 1995;35:131-41.

19. Lai H, Singh NP. Melatonin and a spin-trap compound block radiofrequency electromagnetic radiation-induced DNA strand breaks in rat brain cells. Bioelectromagnetics 1997;18:446-54.

20. Garaj-Vrhovac V, Fucic A, Horvat D. Comparison of chromosome aberration and micronucelus induction in human lymphocytes after occupational exposure to vinyl chloride monomer and microwave radiation. Periodicum Biologorium 1990;92:411-6.

21. Garaj-Vrhovac V, Fucic A, Horvat D. The correlation between the frequency of micronuclei and specific chromosome aberrations in human lymphocytes exposed to microwave radiation in vitro. Mutat Res 1992;281:181-6.
22. Garaj-Vrhovac V. Micronucleus assay and lymphocyte mitotic activity in risk assessment of occupational exposure to microwave radiation. Chemosphere 1999;39:2301-12.

23. Maes A, Collier M, Van Gorp U, Vandoninck S, Verschaeve L. Cytogenetic effects of 935.2-MHz (GSM) microwaves alone and in combination with mitomycin $\mathrm{C}$. Mutat Res 1997;393:151-6.

24. Mashevich M, Folkman D, Kesar A, Barbul A, Korenstein $R$, Jerby $E$, et al. Exposure of human peripheral blood lymphocytes to electromagnetic fields associated with cellular phones leads to chromosomal instability. Bioelectromagnetics 2003;24:82-90.

25. Verschaev L, Slaets D, Van Gorp U, Maes A, Vankerkom $L$. In vitro and in vivo genetic effects of microwaves from mobile telephone frequencies in human and rat peripheral blood lymphocytes. In: Simunic D., ed., Proc. COST-244 Workshop, Bled (Slo), EC, DGXIII, J31, 1994. p. $74-83$.

26. Vasquez MV, Clancy JC, Blackwell DB, Donner MD, Tice $\mathrm{RT}$, Hook GH, et al. Genotoxicity of radio frequency fields generated from analog, TDMA, CDMA and PCS in human blood cells evaluated using the single cell gel (SCG) electrophoresis and the cytochalasin B micronucleus (CBMN) assay. Environ Mol Mutagen 1999;33.(Suppl 30)66.

27. Zeni O, Chiavoni AS, Sannino A, Antolini A, Foroigo D, Bersani $F$, et al. Lack of genotoxic effects (Micronucleus Induction) in human lymphocytes exposed in vitro to 900 $\mathrm{MHz}$ electromagnetic fields. Radiat Res 2003;160:152-8.

28. McNamee JP, Bellier PV, Gajda GB, Lavallee BF, Marro $L$, Lemay $E$, et al. No evidence for genotoxic effects from $24 \mathrm{~h}$ exposure of human leukocytes to $1.9 \mathrm{GHz}$ Radio frequency fields. Radiat Res 2003;159:693-7.

29. Hook GJ, Zhang P, Lagroye I, Li L, Higashikubo R, Moros $E G$, et al. Measurement of DNA damage and apoptosis in Molt -4 cells after in vitro exposure to radio frequency radiation. Radiat Res 2004;161:193-200.

\section{Announcement}

\section{1th International Congress of Human Genetics}

$$
\text { Brisbane Convention \& Exhibition Centre, Brisbane, ustralia }
$$

August 6 - 102006

Abstract submission is now available online at

www.ichg2006.com 